\title{
Instructional Materials and Improvisation in Physics Class: Implications for Teaching and Learning
}

\author{
Aina, Kola Jacob \\ Physics Department College Education (Tech.) Lafiagi Kwara State, Nigeria.
}

\begin{abstract}
This study looked at the availability, uses and improvisation of instructional materials and the implications on teaching and learning of physics in secondary schools. All secondary schools offering physics at WAEC level and one technical college in Edu, Patigi and Ilorin west local government of kwara state formed the sample of this study. 23 physics teachers and 39 physics students participated in the study. Questionnaire contained 64 items for both the teachers and students were designed for the purpose of the study. Frequency and percentages were used to analyse the returned questionnaire; findings revealed shortage of instructional materials; inadequate use of the available ones and teachers' making use of local materials to improvise physics teaching instructional materials. Recommendations were suggested that government should put more money into education especially science education and many more.
\end{abstract}

Keywords: instructional materials, improvisation, learning, community resources.

\section{Introduction}

Physics is a science subject that student often find very difficult and this is why student always have low achievement in the subject. According to Aina and Akintunde (2013) student usually performed very poorly in physics in all level of education. Many researchers have equally supported the view that students performed poorly in physics (Aigbomian, 1994; Uguanyi, 1994; Aiyelabegan, 2003; Akanbi, 2003).

One major reason for this poor performance might not be separated from the abstract nature of the course as observed by Adeyemo (2010). The teaching of physics in schools has not been encouraging due to this abstract nature of the subject that is why the use of instructional materials is needed to facilitate students' learning of physics. Oladejo, Olosunde, Ojebisi and Isola (2011) stressed that mastery of physics concepts cannot be fully achieved without the use of instructional materials.

Another problem confronting teaching and learning of physics in Nigeria is the unavailability of these instructional materials in schools; therefore there is the need for improvisation. Aina (2012) said many of the equipment used in teaching physics can be improvised that is why physics teacher should endeavour to utilize the use of discarded resources around them to improvised teaching aids for physics.

Instructional materials helps teacher to meet individual differences of the learners in the class by using aids that appeal to different senses (Morohunfola, 1983). Instructional materials are used to supplement verbal explanation of concepts or any description so that the lesson could be real to the students. These instructional materials are categorised into audio visual, audio and visual. These are materials that when teacher used them can appeal to student both sight and hearing. These can be electronically operated materials like Television, Radio, Film, Slide motion; Computer and non electronic ones such as Chalk board, Charts, Burners, Models and many more. The absence of these materials in teaching of physics could make the class very uninteresting to student and discourage learning thereby lead to low or poor achievement.

Instructional materials are very important because what students hear can easily be forgotten but what they see cannot be easily forgotten and last longer in their memory. In contribution of Abimbola (1999) to the importance of instructional materials to teaching and learning process, he stressed that the primary purpose of instructional materials is to make learning more effective and also facilitate it. He averred further that teachers would not be able to do much where these materials are not available; therefore improvisation become necessary. Fakomogbon and Adegbija (2006) posited that instructional media or materials can be used by lecturers to overcome noise factors, such as misconception, referent confusion and daydreaming.

In this age of Information and Communication Technology [ICT] teachers must be able to use available local resources to produce instructional and learning materials in schools (Daniel, 2001). As good as improvisation might be in teaching and learning if learners are not taken part in the process of improvisation its aim may not be fully achieved. Learner participating in improvisation of instructional materials makes them exposed to creativity, innovation and curiosity, all of which are fundamental to teaching and learning of science (Adeniran, 2006). Improvisation in science teaching is an important issue in science Education which has attracted a lot of contributions from science teachers (Fatubarin, 2001).

The purpose of this study is to make a survey of the availability and uses of instructional materials in schools, improvisation and the implications for teaching and learning physics. 
Instructional Materials and Improvisation in Physics Class: Implications for Teaching and Learning

\section{Methodology}

The study employed descriptive survey method. The population was all physics teachers and students in kwara state secondary schools while the sampled comprises of all physics teachers and selected students in Edu, Patigi and Ilorin West Local Government Area of Kwara state, Nigeria.

Questionnaire containing 64 items were designed for teachers and students by the researcher to collect information from the sampled schools after due permission was sought from the appropriate authorities of the schools.

Data collected were analyzed using frequency counts and percentages. These methods of analysis were opted for because it is used for organizing and describing the characteristics of educational variables in concise and meaningful quantifiable terms (Daramola, 2006).

Five research questions raised for the purpose of this study were;

1. Are there instructional materials relevant to physics teaching in schools?

2. Do we use instructional materials for physics lesson in schools?

3. Do we have sufficient apparatus in physics laboratory?

4. Do teacher improvised instructional materials and does it aid effective teaching and learning of physics?

5. Do students gain more with the use of improvised materials compared to the readymade ones?

\section{FINDINGS}

Table 1: availability of instructional materials

\begin{tabular}{llll}
\hline $\mathrm{s} / \mathrm{n}$ & Items & No of response & \% Response \\
\hline 1 & Audio tape & 1 & 10 \\
2 & Charts & 7 & 70 \\
3 & Computer set & 2 & 20 \\
4 & Projectors & 2 & 20 \\
5 & Printed materials & 8 & 80 \\
6 & Physics laboratory & 10 & 100 \\
7 & Models & 1 & 10 \\
8 & Radio & 2 & 20 \\
9 & Video & 1 & 10 \\
\hline
\end{tabular}

Table 2: uses of instructional material for teaching

\begin{tabular}{|c|c|c|c|c|c|}
\hline \multirow[t]{2}{*}{$\mathrm{s} / \mathrm{n}$} & \multirow[t]{2}{*}{ Items } & \multicolumn{2}{|c|}{ Response } & \multicolumn{2}{|c|}{ Response } \\
\hline & & Yes & $\%$ & No & $\%$ \\
\hline 1 & Audio tape & 1 & 10 & 9 & 90 \\
\hline 2 & Assignment in textbook & 10 & 100 & 0 & 0 \\
\hline 3 & Charts & 10 & 100 & 0 & 0 \\
\hline 4 & Excursion/field trip & 0 & 0 & 10 & 100 \\
\hline 5 & Improvisation & 8 & 80 & 2 & 20 \\
\hline 6 & Laboratory & 10 & 100 & 0 & 0 \\
\hline 7 & Library & 10 & 100 & 0 & 0 \\
\hline 8 & Internet & 1 & 10 & 9 & 90 \\
\hline 9 & Computer & 2 & 20 & 8 & 80 \\
\hline 10 & Projector & 0 & 0 & 10 & 100 \\
\hline 11 & Printed materials & 7 & 70 & 3 & 30 \\
\hline 12 & Video & 0 & 0 & 10 & 100 \\
\hline 13 & & & & & \\
\hline
\end{tabular}

Table 3: list of available laboratory apparatus

\begin{tabular}{lllll}
\hline & Electricity \& magnetism & & Light and waves & Item available \\
$\mathrm{s} / \mathrm{n}$ & Item & \% available & Lens & 100 \\
\hline 1 & Resistance box & 60 & Rectangular block & 90 \\
2 & Rheostat & 70 & Microscope & 20 \\
3 & Galvanometer & 60 & Ray box & 60 \\
4 & Ammeter \& voltmeter & 70 & Turning fork & 50 \\
5 & Compass needle & 40 & & \\
6 & Resistor & 60 & & \\
7 & 2Volt accumulator & 60 & & \\
8 & Magnet & 10 & & \\
\hline
\end{tabular}


Instructional Materials and Improvisation in Physics Class: Implications for Teaching and Learning

\begin{tabular}{lllll}
\multicolumn{5}{c}{ Table 4: list of available laboratory apparatus } \\
\hline s/n & Item & $\%$ available & Item & \% available \\
\hline 1 & Spring balance & 60 & Thermometer & 70 \\
2 & Spiral spring & 80 & Bunsen burner & 20 \\
3 & Pendulum bob & 50 & Calorimeter & 40 \\
4 & Weights & 10 & Measuring flask & 80 \\
5 & Meter rule & 90 & \\
6 & Measuring cylinder & 10 & \\
7 & Stop watch & 90 & \\
8 & Micrometer screw gauge & 40 & \\
9 & Vernier calliper & 40 & & \\
\hline
\end{tabular}

Table 5: improvisation of instructional materials

\begin{tabular}{llllll}
\hline item & response & No of teacher & $\%$ & No of students & $\%$ \\
\hline \multirow{2}{*}{9} & yes & - & & 28 & 71.8 \\
& no & - & & 11 & 28.2 \\
10 & yes & 11 & 84.6 & - & - \\
& no & 2 & 12.4 & - & - \\
4 & yes & - & & 28 & 71.8 \\
& no & - & & 11 & 28.2 \\
5 & yes & - & & 10 & 74.4 \\
& no & - & & & \\
& & & & & \\
\end{tabular}

Table 6: uses of improvised materials

\begin{tabular}{cccccc}
\hline Item & response & No of teacher & $\%$ & No of students & $\%$ \\
\hline \multirow{2}{*}{6} & yes & 9 & 69.2 & 30 & 79.9 \\
& no & 4 & 30.8 & 9 & 23.1 \\
\hline
\end{tabular}

From table 1 above it was revealed that secondary schools under study did not have audio tapes, projectors, computer set, models, radio and video as the percentage of their availability was very low. All the schools had physics laboratory; many of the school had printed materials and charts. Research question 1 is hereby answered that there is no relevant instructional materials in the schools.

Table 2 confirmed the data in table 1 as majority of the schools don't use audio tape for instruction in their classes. Students are not going for excursion and teachers are not using both projectors and video for classroom instruction. The table equally indicated very poor uses of computer and internet facility in these schools. The schools were very good at using laboratory, library and printed materials. This table answer research question 2 that, schools were not using instructional materials for physics lesson.

Table 3 and 4 revealed that these schools had laboratory apparatus for secondary school physics lesson except for magnet, microscope, compass needle weights, measuring cylinder Bunsen burners, vernier calipers and micrometer screw gauge where the percentages were low. The data in these tables answered research question 3 that there were laboratory apparatus in the schools but not sufficient.

Inference could be drawn from table 5 that teachers were improvising teaching materials and improvised materials aids teacher in his teaching and also help students to learn physics more effectively. By this research question 4 is hereby answered.

From table 6 it was observed that students enjoy or gain more when improvised materials were used for teaching physics. Students also participated in the process of improvisation. This answered research question 5.

\section{Discussion}

Audio tape, projectors, model, radio, computer and video are very important in teaching and learning process in this age of ICT. Nguyen, Williams and Nguyen (2012) listed LCD projector, Computer, Speakers and over-head Projector among the tools that support lectures in classroom. There are some complex concepts that teacher may not be able to teach effectively but with the aid of computer and projectors such concepts could be effectively demonstrated to the students. It is very encouraging to see that school had laboratory because laboratory is very important to the learning of physics; however it is very important to make further study of these laboratories to ascertain their standard. Poor achievement of student may not be separated from unavailability and inadequate use of instructional materials as observed by Oladejo, Olosunde, Ojebisi and Isola (2011)

Community resources is very important to the teaching and learning of science; the result of this study indicating students not going to excursion is not good for effective learning of physics. Besty (2012) affirmed that community service was beneficial to students' learning because of its connection to their prior science.

Further averred that what student learnt in classroom in theory becomes meaningful to students when 
Instructional Materials and Improvisation in Physics Class: Implications for Teaching and Learning

they experience this in the community through excursion. Poor achievement of student in physics could be linked to the way student learnt some concepts; many of these concepts look abstract since they have not seen or come across such concepts in action before.

The presence of laboratories in these schools is good, though out of the scope of this study yet it is germane to think about the standard of these laboratories. Physics laboratories must be built to standard and with correct facilities different from other science subjects (Aina, 2010). Laboratory is one of the factors that affect students' performance in science subject especially in physics (Ajileye, 2006).

Laboratory apparatus is the 'heart' of science learning and where not found or insufficient, students' academic achievement will be very low or poor, this was the argument of Akanbi (2003) that inadequate laboratory equipment and facilities lead to students' poor performance in physics.

The present economic hardships around the world make financing education very difficult especially science; that is why most needed instructional materials are not available in schools. However, something must be done to get alternative that could also serve the same purpose; improvisation is therefore necessary but with caution so that the student will not be misguided. Most of the improvised material lack precision and accuracy in measurement which may eventually be counterproductive in the teaching and learning process.

\section{Conclusion And Recommendations}

In the light of the above findings, this study concludes that there was shortage of instructional materials in secondary schools in these local government areas; teachers are not adequately using instructional materials for teaching physics; students were not going for excursion; there was insufficient supply of laboratory apparatus and improvisation was taken very serious in these schools. The improvised materials had a positive influence on students' learning as it was revealed that it improved students' learning.

The implications this may have on teaching and learning are:

1. Students' academic achievement will be affected negatively;

2. Students will be losing interest in physics;

3. There will be reduction in the number of students offering physics related courses in higher institutions; this is unhealthy for the country technological development; and

4. Students having interest in improvised materials rather than the original standard material is very dangerous because of precision and accuracy of measurement.

The following recommendations were suggested in view of the above conclusion:

Government should put money into education sector purposely for the purchase of instructional materials, laboratory facilities/apparatus, especially, computer is very important in school at this age of ICT. Individuals, corporate bodies, communities and non governmental agencies should not see financing of education as government responsibility alone; they should come in partnership with government to finance science education.

All schools must have internet facility in their schools to ensure students have free access to internet. Teacher should encourage the use of this internet by given assignment to students on internet.

Excursion should form part of students program in school especially for physics; this helps student to explore the potential of community resources for effective learning.

Improvised materials should not take the place of standardized instructional materials; it should only be used for demonstrations unless those ones that were already standardized can be relied upon for any measurement.

The above conclusion could be generalised for all the public schools in the state where the research was carried out because schools in these states were managed and controlled by the same government.

\section{Limitation Of This Study}

The results of this study cannot be generalized for all schools in Nigeria; it could only be applied where possible apart from the state where it was carried out.

Also the interval between the time this research was carried out and the time of publication of the paper may have changed the situation in the sampled schools.

The lists of laboratory apparatus sampled in the study were not the only physics apparatus but the sampled were those commonly used for secondary school physics practical.

\section{Acknowledgment}

First and foremost my sincere appreciation goes to all the authors whose works I cited in writing the report of this research and the managements of the sampled schools. 
Instructional Materials and Improvisation in Physics Class: Implications for Teaching and Learning

\section{References}

[1]. Abimbola, A. (1999). Principles and practice of Educational Technology Ibadan, Nigeria: International publisher

[2]. Adeniran, M.A. (2006). Strategies and utilization of improvised Biology Instructional materials and students' achievement and attitude in Ekiti secondary school, Nigeria. International Journal of Research in Education. 3(2), 91-96

[3]. Adeyemo, S.A. (2010). Teaching/ learning physics in Nigerian secondary school: The curriculum transformation, issues, problems and prospects. International Journal of Educational Research and Technology,1 (1),99-111

[4]. Aigbomian, D.O. (1994). Student's perception of technical words in the learning of physics. Studies in Education 2 (1): $86-92$

[5]. Aina, J.K. (2010). The Prospective Physics Teacher. Basic Concepts in Science 2,Ilorin, Nigeria: The author.

[6]. Aina, J.K. (2012). Teaching aids improvisation in the teaching and learning of physics in secondary chools Retrieved from "http://www.articlesbase.com/science-articles/teaching-aids-improvisation-in-the-teaching-and-learning-of-physics-in-secondaryschools-5675240.html

[7]. Aina, J.K. \& Akintunde, Z.T. (2013). Analysis of gender performance in physics colleges of education, Nigeria. Journal of Education and Practice, 4(6). ISSN 2222-288X

[8]. Aiyelabegan, T,A (2003). Effect of physics practical on students' academic performance in senior chool certificate examination in Kwara state. Lafiagi Journal of Science Education. $1 \& 2,34$

[9]. Ajileye , O.O. (2006).Towards effective science education: Issues in universal basic education programme. Journal of Sports Management and Educational Research. 1 (2), 337.

[10]. Akanbi, A.O. (2003). An investigation into students' performance in senior secondary school physics. Journal of Teacher education trends $1(1), 58-64$

[11]. Besty, L.N. (2012). The application of community service learning in science education. Asia- Pacific Forum on Science Learning and Teaching, 13(2) Article 15,

[12]. Daniel, I.Y (2001, September). Improvisation and use of instructional materials in science teaching, A paper presented at NCCE/UNESCO Workshop For train the trainers' workshop. Kotangora.Daramola, S.A., (2006). Research and statistical method in education for students and researchers in tertiary institutions. Ilorin, Nigeria: The author.

[13]. Fakomogbon, M.A \& Adegbija, M.V (2006). Instructional media and their Sources for teaching and learning in tertiary institution; A Nigeria perspective. African Journal of Educational Studies. 4 (2), 128

[14]. Fatubarin, A (2001). The challenge of improvisation in science teaching in the present day Nigeria. Journal of committee of Provosts of colleges of Education, Nigeria. 1 (1),92.

[15]. Morohunfola, P.I (1983). A study of relationship between instructional resources and students' academic performance. (Unpublished master's thesis) University of Ilorin, Ilorin, Nigeria.

[16]. Nguyen, N, Williams, J \& Nguyen, T. (2012). The use of ICT in teaching tertiary physics: Technology and pedagogy. Asia-Pacific Forum on Science Learning and Teaching.13 (2) Article 6,1

[17]. Oladejo, M.A, Olosunde,G.R, Ojebisi,A.O \& Isola,O.M. (2011). Instructional materials and students' academic achievement in physics: some policyimplications. European Journal of Humanities and Social Sciences, 2(1), ISSN 2220-9425

[18]. Uguanyi, J.U., (1994). Aids: A threat to African survival. Discovering and Innovation 8 (1): 30-34 